\title{
Effects of temperature on growth rate, cell composition and nitrogen metabolism in the marine diatom Thalassiosira pseudonana (Bacillariophyceae)
}

\author{
John A. Berges*, Diana E. Varela**, Paul J. Harrison \\ Department of Earth and Ocean Sciences, University of British Columbia, Vancouver, British Columbia V6T 1Z4, Canada
}

\begin{abstract}
Although temperature effects on phytoplankton growth and photosynthesis can be clearly demonstrated in the laboratory, their relevance in the field is much harder to establish. Recently, however, it has been recognized that temperature has a significant influence on nitrogen uptake. In particular, temperate marine diatom species may be limited by their ability to acquire nitrate at temperatures above approximately $16^{\circ} \mathrm{C}$. In order to explore this idea, we grew the diatom Thalassiosira pseudonana at 8,17 and $25^{\circ} \mathrm{C}$, and compared cell composition, and rates of growth $(\mu)$, ${ }^{15} \mathrm{~N}$ incorporation, calculated nitrate incorporation (the product of $\mu$ and cell $\mathrm{N}$ content), and the activity of nitrate reductase (NR), a key enzyme involved in nitrate incorporation. Cell $\mathrm{N}$ content, protein and volume remained relatively constant across different temperatures, but cell $\mathrm{C}$, chlorophyll $a$ (chl a), and C:N ratio increased with increasing temperature, suggesting that $\mathrm{C}$ metabolism was affected more strongly than $\mathrm{N}$ metabolism. Classical temperature models suggested that growth and various indices of nitrate metabolism all responded to temperature, with $Q_{10}$ values of close to 2 over the whole temperature range. However, $Q_{10}$ values over the interval from 8 to $17^{\circ} \mathrm{C}$ were higher than 2 and much lower than 2 between 17 and $25^{\circ} \mathrm{C}$. Limitations to the $Q_{10}$ concept are considered. Temperature effects on different measures of nitrate metabolism were very similar, supporting the hypothesis that the effects of temperature on diatom nitrate metabolism are mediated at the level of NR activity. Recent biochemical data for NR also supports this idea.
\end{abstract}

KEY WORDS: Nitrate reductase $\cdot$ Enzyme activity $\cdot{ }^{15} \mathrm{~N}$ uptake $\cdot$ Phytoplankton ecology $\cdot$ Chemical composition $\cdot$ Temperature adaptation

\section{INTRODUCTION}

Although there can be little doubt that temperature exerts a strong influence on algal growth and photosynthesis (e.g. Raven \& Geider 1988, Davison 1991), biological oceanographers have tended to concur with Eppley's

Present addresses:

*School of Biology and Biochemistry, Queen's University, Belfast BT9 7BL, Northern Ireland, UK.

E-mail: j.berges@qub.ac.uk

${ }^{* *}$ Marine Sciences Institute, University of California at Santa

Barbara, California 93106, USA
(1972) observation that 'temperature does not seem to be very important in the production of phytoplankton in the sea'. Indeed, temperature does not even appear as a variable in a recent review of phytoplankton primary productivity models (Behrenfeld \& Falkowski 1997). Reasons for this apparent contradiction, include the fact that effects of temperature can be overshadowed by factors such as irradiance (e.g. Gibson \& Foy 1989), and the considerable ability of phytoplankton to acclimate or adapt to growth at different temperatures (e.g. Li 1980, Smith et al. 1994, Suzuki \& Takahashi 1995).

Temperature effects on algal metabolism extend beyond growth and photosynthesis, however. There is 
a large body of literature showing that temperature affects cell composition, short-term nutrient uptake and, in particular, nitrogen metabolism (see Morris et al. 1974, Yoder 1979, Terry 1983, Raimbault 1984, Whalen \& Alexander 1984, Thompson et al. 1992, Reay et al. 1999, Sakamoto \& Bryant 1999). These effects, while more subtle than those on growth and photosynthesis, can have enormous implications at the level of the ecosystem. Recently, for example, Lomas \& Glibert $(1999 a, b)$ proposed that diatoms and diatom nitrate uptake are strongly limited by temperature; this has important implications for species succession and the biogeochemistry of nitrogen in marine environments.

In order to investigate such effects, it is necessary to examine both cellular and subcellular processes. The effects of temperature are usually considered to have their basis in altering enzyme-mediated biochemical processes. The relationship between temperature and a given biological rate can be modelled in several different ways (see Ratkowsky et al. 1983, Ahlgren 1987), but the temperature coefficient $Q_{10}$ (the factor by which a biological rate is increased by a $10^{\circ} \mathrm{C}$ rise in temperature) has been most commonly used. The use of $Q_{10}$ values assumes an Arrhenius-type relationship between rates and temperature and relies on chemical kinetics controlling the observed rate (Ahlgren 1987). Under such conditions, biochemical processes are expected to have a $Q_{10}$ near 2 . There are relatively few examples where the effects of temperature on physiological and biochemical processes have actually been examined simultaneously.

Previous work considering the effects of temperature on nitrogen metabolism is somewhat disjointed. We know, for example, that nitrogen uptake can show a pattern of increase, optimum and rapid decline as temperature is increased (Rhee \& Gotham 1981, Terry 1983, Whalen \& Alexander 1984), that there can be a pronounced uncoupling between transient uptake and assimilation of nitrogen at lower temperatures (Raimbault 1984), and that the activity of nitrogen-reducing enzymes such as nitrate reductase (NR) varies strongly with temperature (Kristiansen 1983). Recent work by Gao et al. (2000) provided some evidence of the biochemical basis for the observations of Lomas \& Glibert $(1999 a, b) ;$ NR from the diatom Skeletonema costatum shows optimal activity at a relatively low temperature and is unstable above $\sim 16^{\circ} \mathrm{C}$.

In the present study, we examined the effects of temperature on cell composition, nitrate uptake and incorporation, nitrate reduction (catalyzed by NR) and ultimately on rates of growth, represented by the rate of cell division rate, in near-steady-state cultures of the marine diatom Thalassiosira pseudonana. This represents one of the first attempts to compare ecological, physiological and biochemical rates to deduce at what level temperature is acting. Our hypothesis was that observed changes in nitrate incorporation can be explained by changes at the biochemical level, i.e. in NR activity.

\section{MATERIALS AND METHODS}

Culture conditions. Cultures of the marine diatom Thalassiosira pseudonana (Clone $3 \mathrm{H}$ ) were obtained from the Northeast Pacific Culture Collection and grown in $1 \mathrm{l}$ semi-continuous batch cultures on artificial medium, under continuous light (150 $\mu \mathrm{mol}$ quanta $\mathrm{m}^{-2} \mathrm{~s}^{-1}$ ), as previously described (Berges \& Harrison 1993). All nutrients were in excess, and the sole nitrogen source (nitrate) was maintained at $>20 \mu \mathrm{M}$ at all times. Cultures were stirred and bubbled gently with air. Triplicate cultures were grown at either $8 \pm 1^{\circ} \mathrm{C}, 17$ $\pm 1^{\circ} \mathrm{C}$ or $25 \pm 1^{\circ} \mathrm{C}$ using a combination of a circulating cooled water bath and immersion heaters. The semicontinuous cultures were acclimated for a minimum of 8 generations by diluting to one-sixth their original density as they neared the end of the logarithmic phase of growth. Growth rates were monitored by in vivo fluorescence measured in a Model 10-AU fluorometer (Turner Designs, Sunnyvale, CA), or by cell counts (see next subsection). All sampling was performed on mid-log-phase cultures. Under these conditions, growth can be maintained at a constant rate virtually indefinitely, and cell composition is essentially invariant over time (e.g. Berges \& Harrison 1995a,b).

Cell composition measurements. Cell counts and cell volume determinations were performed on living cells using a Model TAII counter (Beckmann Coulter, Brea, CA) equipped with a population accessory. A $70 \mu \mathrm{m}$ aperture was used, and the instrument was calibrated with $5 \mu \mathrm{m}$ latex microspheres. Chl a was measured fluorometrically in samples collected by filtration onto $25 \mathrm{~mm}$ GF/F glass-fibre filters, and extracted in $90 \%$ acetone (Parsons et al. 1984). Samples taken on precombusted $13 \mathrm{~mm}$ Gelman A/E filters were analyzed for nitrogen and carbon content using a CNS analyzer (Carlo Erba, Milan, Italy), with sulfanilamide as a standard. Protein was determined using a modified Bradford method (described in Berges et al. 1993), homogenizing samples filtered onto $25 \mathrm{~mm}$ GF/F filters in TCA, and resolublizing proteins in $1 \mathrm{~N} \mathrm{NaOH}$.

Nitrogen metabolism. Nitrate uptake rates were measured using the stable isotope ${ }^{15} \mathrm{~N}$. Duplicate samples from each culture were inoculated with $10 \mu \mathrm{M}$ ${ }^{15} \mathrm{NO}_{3}{ }^{-}$and incubated at 8,17 or $25^{\circ} \mathrm{C}$ alongside the original cultures in $500 \mathrm{ml}$ polycarbonate bottles for 3 to $4 \mathrm{~h}$. After incubation, samples for ${ }^{15} \mathrm{~N}$ analysis were collected on precombusted GF/F filters and analyzed using the micro-Dumas dry-combustion technique, as 
described by La Roche (1983) and Harrison (1983), and a Model N-150 (Jasco International, Tokyo, Japan) emission spectrometer (Fiedler \& Proksch 1975). Nitrate uptake rates were calculated following Dugdale \& Wilkerson (1986).

In vitro assays for nitrate reductase (NR) were performed as described in Berges \& Harrison (1995a), monitoring production of nitrite colourimetrically. Duplicate samples from each culture were collected on GF/F filters and homogenized. Subsamples of each homogenate were assayed at all temperature, i.e. 8, 17 and $25^{\circ} \mathrm{C}$.

Rates of nitrate incorporation in cultures at the temperature of acclimation were also calculated as the product of specific growth rate $(\mu)$ and particulate nitrogen per cell (PN).

Analyses. For rates of growth, ${ }^{15} \mathrm{~N}$ uptake, NR activity and calculated nitrate incorporation, values of $Q_{10}$ and activation energy $\left(E_{\mathrm{a}}\right)$ were calculated across temperature intervals as:

and

$$
\ln Q_{10}=\frac{10\left(\ln V_{2}-\ln V_{1}\right)}{\left(T_{2}-T_{1}\right)}
$$

$$
\ln E_{a}=\frac{R\left(\ln V_{2}-\ln V_{1}\right)}{\left(T_{1}-T_{2}\right)}
$$

where $V_{1}$ and $V_{2}$ are rates of reaction at temperatures $T_{1}$ and $T_{2}$ (in ${ }^{\circ} \mathrm{K}$ ), and $R$ is the gas constant.

Comparisons of growth rates, cell composition and rates of nitrogen metabolism at different temperatures were made using 1-way ANOVA designs followed by Tukey multiple comparisons, using SigmaStat Version 1.0 (Jandel Scientific, San Rafael, CA); all tests were made at the $95 \%$ confidence level.

\section{RESULTS}

In terms of cell composition, there were no significant differences in particulate nitrogen (Fig. $1 C_{i} \mathrm{p}>$ 0.1 ), protein (Fig. $1 B_{i} p>0.2$ ) or cell volume (Fig. 1F; $p>0.4$ ) among different temperatures. Particulate carbon per cell increased with increasing temperature (Fig. $1 \mathrm{~A}_{i} \mathrm{p}<0.05$ ), as did the $\mathrm{C}: \mathrm{N}$ ratio (Fig. $1 \mathrm{E}_{i} \mathrm{p}<$ 0.01 ) and chl a per cell (Fig. 1D; $\mathrm{p}<0.01$ ); the magnitude of increases between 17 and $25^{\circ} \mathrm{C}$ was greater than those between 8 and $17^{\circ} \mathrm{C}$.

For rate measurements, $Q_{10}$ values differed substantially depending on the temperature interval used for the calculation. In general, rates calculated over the whole range from 8 to $25^{\circ} \mathrm{C}$ tended to be near 2, while those from 8 to $17^{\circ} \mathrm{C}$ were greater than 2 (Table 1). Between 17 and $25^{\circ} \mathrm{C}$, some rates $\left({ }^{15} \mathrm{~N}\right.$ uptake and NR activity) actually declined, resulting in $Q_{10}$ values of $<1.0$. Growth rate increased between 8 and $17^{\circ} \mathrm{C}$ with a $Q_{10}$ of $>3$, but there was a substantially smaller change be-
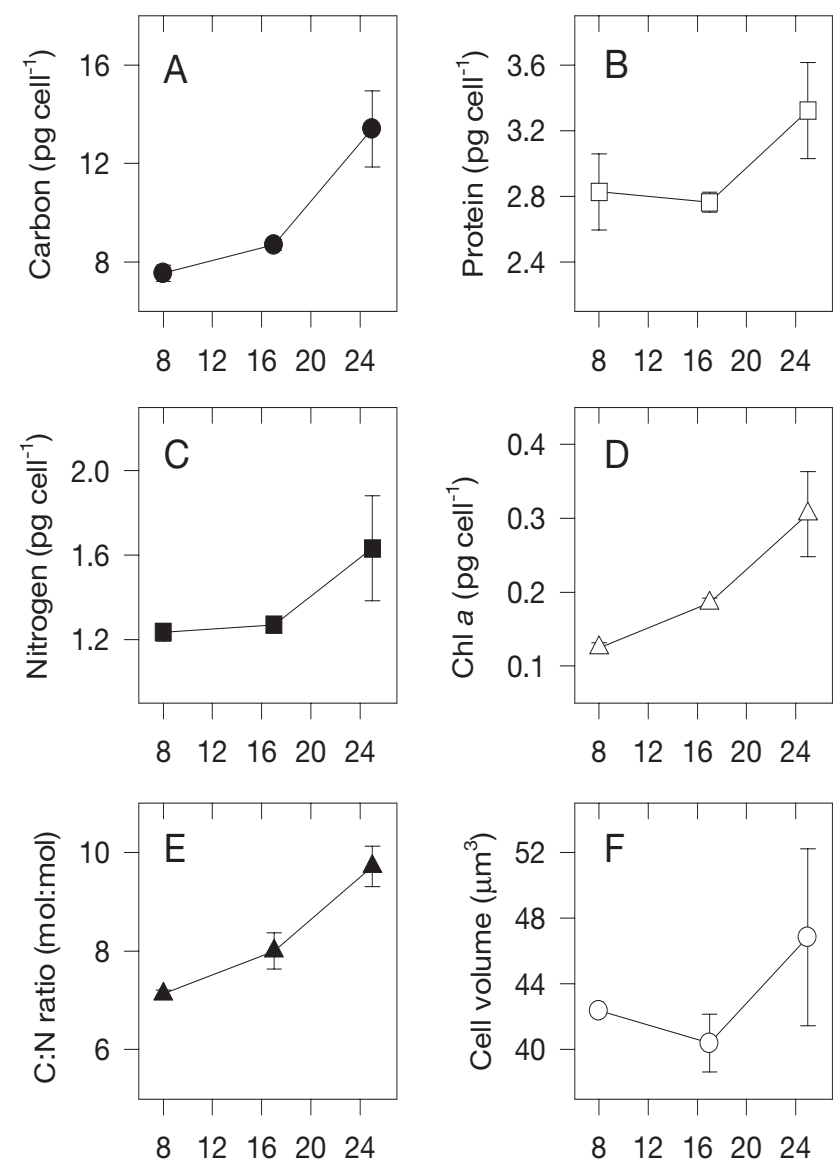

Fig. 1. Thalassiosira pseudonana. Cell constituents in cultures grown under continuous saturating irradiance at different temperatures. (A) particulate carbon; (B) protein; (C) particulate nitrogen; (D) $\mathrm{chl} a_{i}$ (E) carbon:nitrogen molar ratio; (F) cell volume. Cells were grown in semi-continuous batch cultures and acclimated to each temperature for a minimum of 8 generations before sampling; all cultures were in midlogarithmic phase when sampled. Each point represents the mean $( \pm \mathrm{SE})$ of 3 replicate cultures; where error bars are not visible, they are smaller than the symbol

Table 1. Thalassiosira pseudonana. Values of $Q_{10}$ and apparent activation energy $\left(E_{\mathrm{a}}, \mathrm{kJ} \mathrm{mol}^{-1}\right.$, in parentheses) for growth rate $(\mu),{ }^{15} \mathrm{~N}$ uptake, and NR activity and calculated nitrate incorporation rate (the product of $\mu$ and particulate nitrogen per cell, PN) over different temperature ranges, for diatom cultures. Variables were measured in triplicate log-phase cultures acclimated to the temperature of measurement for a minimum of 8 generations. $Q_{10}$ and $E_{a}$ were calculated as described in last subsection of 'Materials and methods'

\begin{tabular}{|llll|}
\hline Variables & 8 to $17^{\circ} \mathrm{C}$ & 17 to $25^{\circ} \mathrm{C}$ & 8 to $25^{\circ} \mathrm{C}$ \\
\hline$\mu$ & $3.09(76.3)$ & $1.19(12.6)$ & $1.97(46.0)$ \\
${ }^{15} \mathrm{~N}$ uptake & $2.88(71.6)$ & $0.98(-0.95)$ & $1.65(33.9)$ \\
NR activity & $2.71(67.3)$ & $0.95(-3.9)$ & $1.74(37.5)$ \\
$\mu \mathrm{PN}$ & $3.18(78.2)$ & $1.63(35.1)$ & $2.32(57.0)$ \\
\hline
\end{tabular}




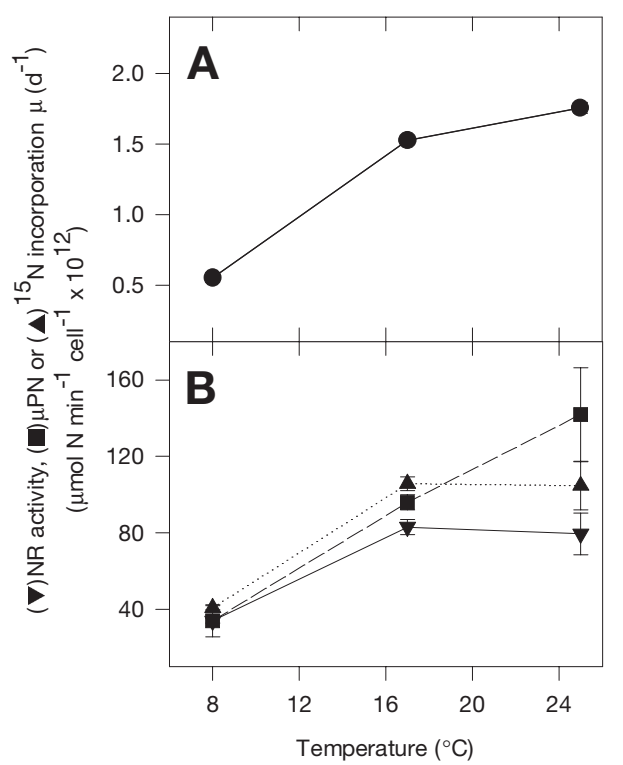

Fig. 2. Thalassiosira pseudonana. Rates of growth (A) and indices of nitrogen incorporation (B) in cultures grown under continuous saturating irradiance at different temperatures. Growth was calculated from changes in cell number. Nitrogen incorporation was estimated as nitrate reductase (NR) activity $(\boldsymbol{\nabla})$, rate of nitrogen incorporation as the product of specific growth rate $(\mu)$, and cell nitrogen content $(\mathrm{PN}, \boldsymbol{\square})$, or rate of ${ }^{15} \mathrm{~N}$-nitrate uptake ( $\boldsymbol{\Delta})$. Culture conditions and sampling as in Fig. 1

tween 17 and $25^{\circ} \mathrm{C}$ (Fig. 2A, Table 1). NR activity, ${ }^{15} \mathrm{~N}$ uptake and calculated rates of nitrate incorporation $(\mu \mathrm{PN})$ were not significantly different from each other at any temperature (Fig. 2B; $\mathrm{p}>0.05$ in all cases). In terms of rate constants, the $Q_{10}$ and $E_{\mathrm{a}}$ for NR activity, ${ }^{15} \mathrm{~N}$ uptake and calculated rates of nitrate incorporation were very close to those for growth rate between 8 and

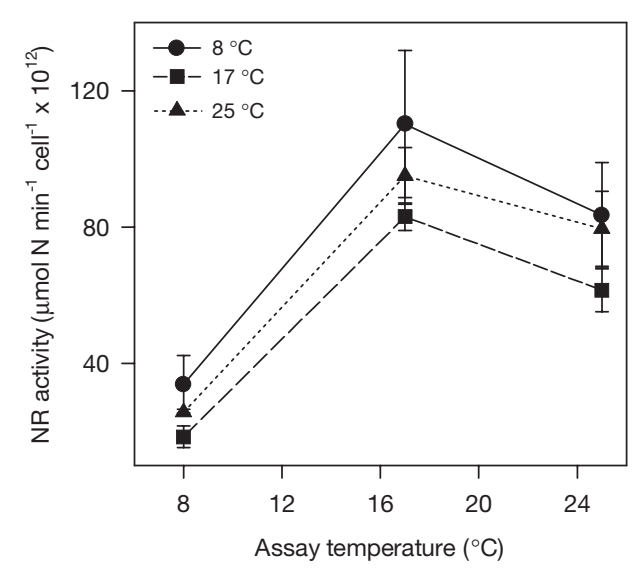

Fig. 3. Thalassiosira pseudonana. Nitrate reductase (NR) activity in cultures grown at 8,17 or $25^{\circ} \mathrm{C}$ and assayed at different temperatures. Culture conditions, sampling and symbols as in Fig. 1 $17^{\circ} \mathrm{C}$ (Table 1). Between 17 and $25^{\circ} \mathrm{C}, Q_{10}$ and $\mathrm{E}_{\mathrm{a}}$ for NR activity and ${ }^{15} \mathrm{~N}$ uptake rates were no different from each other $(p>0.1)$; although rate constants for $\mu \mathrm{PN}$ appeared to be higher than for ${ }^{15} \mathrm{~N}$ uptake rates or NR activities (Table 1), these differences were not statistically significant $(\mathrm{p}>0.05)$.

When NR activity was plotted against assay temperature, trends were similar for cultures grown at different temperatures (Fig. 3). A 2-way ANOVA examining the effects of growth temperature and assay temperature showed no significant differences between NR activity of cultures that were grown at different temperatures and assayed at a common temperature $(p>$ 0.1 ), and no interactions between growth temperature and assay temperature $(p>0.1)$. Significant differences were found between assay temperatures $(p<$ $0.05)$, regardless of the temperature at which cultures had been grown; NR activity was lower at $8^{\circ} \mathrm{C}$ and not significantly different between 17 and $25^{\circ} \mathrm{C}$.

\section{DISCUSSION}

\section{Temperature and cell composition}

The results for cell composition are largely consistent with previous findings: increasing $\mathrm{C}$ content and chl $a$ content with increasing temperature have been noted many times before for algae in general (see Thompson et al. 1992), and diatoms in particular (e.g. Lomas \& Glibert 1999a, Gao et al. 2000). There is more variability in the results for cell volume. In some cases, increasing volume with increasing temperature has been noted by some investigators (e.g. Lomas \& Glibert 1999a), while others have found no changes (e.g. Gao et al. 2000). This may be related to the light regime: cell volume increases tend to occur in studies using a light:dark cycle (e.g. Lomas \& Glibert 1999a), as opposed to continuous light (as in the present study).

The finding that $\mathrm{C}: \mathrm{N}$ ratio increases with increasing temperature is generally supported by other data (e.g. Thompson et al. 1992), but this may also depend on the light regime, since Lomas \& Glibert (1999a) noted no changes in $\mathrm{C}: \mathrm{N}$ ratio with temperature in diatoms and dinoflagellates grown on light:dark cycles. In the present study, the increase in C:N ratio was largely the result of increased carbon content without changes in nitrogen. Yoder (1979) found that in the diatom Skeletonema costatum, $\mathrm{N}$ content was largely independent of temperature under light limitation, and this seems also to be the case where light is not limiting. The mechanism of this change remains unclear. Raven \& Geider (1988) hypothesized that algae grown at low temperature could commit a larger fraction of cell carbon to catalysts than algae at higher temperatures. If 
so, assuming that catalysts are enzyme proteins, we might expect that low-temperature-acclimated cells would have relatively more carbon tied up in protein than those at higher temperatures, and thus the C:N ratio would be lower at low temperatures. However, were this the case, we might also expect to see changes in protein, which were not observed. Similarly, Gao et al. (2000) did not detect any changes in cell protein in $S$. costatum grown at temperatures between 5 and $25^{\circ} \mathrm{C}$. Alternatively, temperature could affect rates of carbon and nitrogen incorporation differentially.

\section{The $Q_{10}$ concept}

Before comparing the results of the various measurements of rates of growth and nitrogen metabolism, it is necessary to evaluate the $Q_{10}$ and $\mathrm{E}_{\mathrm{a}}$ calculations. Both measurements varied considerably, depending on the temperature interval chosen. Correct use of a $Q_{10}$ value implies that the data follows an Arrhenius-type relationship (linearity of a log vs inverse absolute temperature). Several authors have argued against such functions, advocating Belehradek or empirical square-root relationships instead (see Ratkowsy et al. 1983, Ahlgren 1987). One of the important failings of the $Q_{10}$ concept is that it is almost certain that different processes become limiting at different temperature (see Jumars et al. 1993). For example, for photosynthesis, photosynthetic electron transport is probably limiting at lower temperatures, while processes related to transport and fixation of carbon are probably limiting at higher temperatures (see Davison 1991).

However, rather than simply abandoning the use of $Q_{10}$ as a means to describe and predict temperature effects on metabolic rates, we suggest that $Q_{10}$ could be used in a more fundamental way to provide information about the temperatures to which organisms are adapted. Such an idea is, in fact, quite common in the zoological literature; for example, Brown (1989) defined the ranges of temperature in which fishes experienced thermal stress as the ranges of temperature in which oxygen consumption changed by a $Q_{10}>4$. Such a region could be defined for algae based on growth rate: Jitts et al. (1964) examined cell division of 5 species of microalgae and was able to identify ranges of 6 to $10^{\circ} \mathrm{C}$, outside of which the $Q_{10}$ for growth varied considerably around 2 . Such a region could be defined for enzyme activities as well; Burke (1995) identified regions of temperature stability based on enzyme kinetics that he termed a 'thermal kinetic window' (TKW), i.e. the range in which the effective $K_{\mathrm{m}}$ for an enzyme was within $200 \%$ of the minimum observed. For higher plants, this was usually in the 5 to $8^{\circ} \mathrm{C}$ ranges (and was thus much less than the range of tem- perature in which plants were capable of growing). Such a concept has not been applied to phytoplankton to our knowledge.

\section{Temperature effects on growth}

Considerable data are available on the effects of temperature on algal growth; however, results are usually based either on changes in the rate of cell division (i.e. $\mu$, largely in laboratory studies), or on rates of carbon fixation (largely in fieldwork). In order to compare our results across these data sets, we make the assumption that growth and photosynthesis are closely linked and that cell composition is relatively constant. While such assumptions are almost certainly false in particular cases (see preceeding subsection), it nonetheless appears that both growth and photosynthetic rates respond to temperature with an apparent $Q_{10}$ near 2 (Eppley 1972, Raven \& Geider 1988, Davison 1991); a more precise value of 1.88 is often quoted (see Raven \& Geider 1988). If the whole temperature range of growth rate data is considered in the present study, a quite similar value of $Q_{10}(1.97)$ is found, but this differs considerably depending on the temperature interval chosen. In general, diatoms do not appear to be exceptional to the general rule for algae. Lomas \& Glibert (1999a) found a $Q_{10}$ of 2.46 for Thalassiosira weissflogii grown between 10 and $20^{\circ} \mathrm{C}$, and Smith et al. (1994) and Suzuki \& Takahashi (1995) quote values in the neighbourhood of 1.9 for a variety of other species. As in the present study, Thompson et al. (1992) noted for $T$. pseudonana that values of $Q_{10}$ varied between 1.8 and 3.1, depending on the particular range of temperatures selected. Interestingly, Suzuki \& Takahashi noted, for 8 Arctic diatom species, that the temperatures at which maximal growth rates were found were all very near the upper limit for growth and generally higher than the temperature from which the species were isolated. This suggests that temperature could be an important factor for these species and that the range of growth itself is less important ecologically than some smaller subset of this range (see preceeding subsection).

It has been noted for photosynthesis that the stability of enzymes associated with carbon fixation (e.g. ribulose bisphosphate carboxylase/oxygenase: $\mathrm{RuBisCO}$ ) generally exceeds that of whole-plant photosynthesis, i.e. enzymes are less temperature-sensitive than the integrated process in which they participate (see Davison 1991). Moreover, Devos et al. (1998) showed that, in a number of Chloromonas species (both psychrophiles and species adapted to higher temperatures), growth rates, rates of photosynthesis and activities of Rubisco have similar thermal optima and Rubisco 
enzymes from different isolates have similar thermostability. Such findings contrast with the case for NR (see next subsection).

\section{Temperature effects on nitrate metabolism}

Effects of temperature on NR activities and other indices of nitrate incorporation appear to be consistent with each other, within the errors of the measurements. While such correlations cannot prove causation, the results do support the hypothesis that temperature effects on nitrate metabolism are mediated at the enzyme level. Of particular interest is the lack of change in nitrate metabolism between 17 and $25^{\circ} \mathrm{C}_{i}$ directly measured rates of ${ }^{15} \mathrm{~N}$ uptake and NR activity are virtually unchanged, and although rates calculated from $\mathrm{N}$ content and cell division rates do appear to increase, they are not statistically different. This is evidence that the processes of $\mathrm{N}$ acquisition are more sensitive to temperature than are cell division and photosynthesis in diatoms, and fits very nicely with Lomas \& Glibert's (1999a,b) hypothesis. More recently, Lomas \& Glibert (2000) have provided additional evidence that the critical step is that catalyzed by NR and not nitrite reductase (NiR). Their work has also highlighted differences between diatoms and flagellate species that can be related to differing temperature optima for NR.

In reviewing the algal literature, it appears that temperature optima and general characteristics of nitrate uptake and NR activities tend to be very similar in a variety of species including cyanobacteria (e.g. Shukla \& Kashyap 1999) and dinoflagellates (Kristiansen 1983, Witt et al. 1999). Temperature responses of NR are also similar: Witt et al. (1999) found $E_{\text {a }}$ values for NR from Peridinium gatunense of 23 to $29 \mathrm{~kJ} \mathrm{~mol}^{-1}$; Kristiansen (1983), derived an $E_{\mathrm{a}}$ of $38 \mathrm{~kJ} \mathrm{~mol}^{-1}$ for NR from Heterocapsa triqueta; and Gao et al. (1993) calculated an $E_{\mathrm{a}}$ of $36.5 \mathrm{~kJ} \mathrm{~mol}^{-1}$ for NR from Skeletonema costatum, all very similar to the overall value found in the present study.

NR activity from a wide number of marine species from lineages containing chl $c$ show thermal optima in the range of 10 to $20^{\circ} \mathrm{C}$ (e.g. Kristiansen 1983, Davison \& Davison 1987, Gao et al. 1993), Interestingly, all the available data for diatom NR seem to suggest very similar thermal optima for the enzyme, near $16^{\circ} \mathrm{C}$. This temperature is not well related to the temperature from which the phytoplankton have been isolated (see Packard et al. 1971, Kristiansen 1983, Gao et al. 1993), and this remains something of a puzzle. Such an optimum is much lower than that found for green algae and higher plants (e.g. Solomonson \& Vennesland 1972, Solomonson \& Barber 1990, Loppes et al. 1996). This difference has been discussed in an evolutionary context (Gao et al. 2000). Intriguingly, Kudo et al. (2000) have recently demonstrated that NR from Phaeodactylum tricornutum shows very little variation in activity with changing temperature. This result contrasts with many other studies in diatoms (e.g. Kristiansen 1983 and Gao et al. 2000), and may indicate fundamental differences between $P$. tricornutum and other species.

\section{Thermal regulation of NR activity}

How is the effect of temperature on diatom NR mediated? Based on previous work, NR activity in diatoms such as Thalassiosira weissflogii appears to be regulated largely by synthesis (e.g. Gao et al. 2000); to a first approximation, a continuous background degradation accomplishes its turnover (see Vergara et al. 1998). In contrast to NR, which is rather labile in diatoms (e.g. Kristiansen 1983, Gao et al. 1993), proteolytic enzymes in phytoplankton are remarkably thermostable (Berges \& Falkowski 1996). We can hypothesize that, as temperature increases, the activities of the proteases that normally degrade NR also increase. Thus, without any more complicated cellular regulation, increased temperature should lead to greater degradation of NR and not necessarily to greater synthesis; lower NR activity could simply be a consequence of these features of the enzyme's regulation.

In reality, regulation of NR may be much more complicated. Simply changing the quantity (and thus activity) of enzymes is a relatively poor strategy for dealing with temperature changes; altering enzyme kinetic constants (e.g. $K_{\mathrm{m}}$ ) through post-translational modification, or through temperature-specific expression of isozymes are more efficient and often-used strategies (see Graham \& Patterson 1982, Burke 1995). With respect to algal nitrogen metabolism, nothing is yet known about such strategies.

As mentioned above, Gao et al. (2000) hypothesised that there are significant evolutionary differences between NR from green algae and higher plants and NR from chromophytes. One way in which this manifests itself is in the light regulation of NR: higher plants show a phosphorylation mechanism (Huber et al. 1992), while diatoms do not (Berges 1997, Vergara et al. 1998). Curiously, earlier work (Nussaume et al. 1995) demonstrated that NR from higher plants carries an N-terminal domain that is not conserved in other organisms. When the $\mathrm{N}$-terminal domain is removed from tobacco NR, not only is post-translational light regulation abolished, but the thermal optimum of the enzyme shifts from 30 down to near $15^{\circ} \mathrm{C}$. We have no diatom NR sequences at present but, when they are available, it will be interesting to compare $\mathrm{N}$-terminal sequences. 
Acknowledgements. We thank Steve Ruskie for valuable technical assistance. Comment from Mike Lomas and 2 anonymous referees substantially improved the manuscript. J.A.B. was supported in part by a Killham pre-doctoral fellowship.

\section{LITERATURE CITED}

Ahlgren G (1987) Temperature functions in biology and their application to algal growth constants. Oikos 49: $177-190$

Behrenfeld M, Falkowski P (1997) A consumer's guide to phytoplankton primary productivity models. Limnol Oceanogr 42:1479-1491

Berges JA (1997) Algal nitrate reductases. Eur J Phycol 32: $3-8$

Berges JA, Falkowski PG (1996) Cell-associated proteolytic enzymes from marine phytoplankton. J Phycol 32:566-574

Berges JA, Harrison PJ (1993) Relationship between nucleoside diphosphate kinase activity and light-limited growth rate in the marine diatom Thalassiosira pseudonana (Bacillariophyceae). J Phycol 29:45-53

Berges JA, Harrison PJ (1995a) Nitrate reductase activity quantitatively predicts the rate of nitrate incorporation under steady state light limitation: a revised assay and characterization of the enzyme in three species of marine phytoplankton. Limnol Oceanogr 40:82-93

Berges JA, Harrison PJ (1995b) Relationships between nitrate reductase activity and rates of growth and nitrate incorporation under steady-state light or nitrate limitation in the marine diatom Thalassiosira pseudonana (Bacillariophyceae). J Phycol 31:85-95

Berges JA, Fisher AE, Harrison PJ (1993) A comparison of Lowry, Bradford, and Smith protein assays using different protein standards and protein purified from the marine diatom Thalassiosira pseudonana. Mar Biol 115:187-193

Brown LR (1989) Temperature preferences and oxygen consumption of three species of Sculpin (cottus) from the Pit River drainage California USA. Environ Biol Fish 26: $223-226$

Burke J (1995) Enzyme adaptation to temperature. In: Smirnoff $N$ (ed) Environment and plant metabolism: flexibility and acclimation. Bios Scientific Publishers, Oxford, p 63-79

Davison IR (1991) Environmental effects on algal photosynthesis: temperature. J Phycol 27:2-8

Davison IR, Davison JO (1987) The effect of growth temperature on enzyme activities in the brown alga Laminaria saccharina. Br J Phycol 22:77-87

Devos N, Ingouff M, Loppes R, Matagne RF (1998) Rubsico adaptation to low temperatures: a comparative study in psychrophili and mesophilic unicellular algae. J Phycol 34: 655-660

Dugdale RC, Wilkerson FP (1986) The use of ${ }^{15} \mathrm{~N}$ to measure nitrogen uptake in eutrophic oceans; experimental considerations. Limnol Oceanogr 31:673-689

Eppley R (1972) Temperature and phytoplankton growth in the sea. Fish Bull 70:1063-1085

Fiedler R, Proksch G (1975) The determination of nitrogen-15 by emission and mass spectrometry in biochemical analysis: a review. Anal Chim Acta 78:1-62

Gao Y, Smith GJ, Alberte RS (1993) Nitrate reductase from the marine diatom Skeletonema costatum. Biochemical and immunological characterization. Plant Physiol (Bethesda) 103:1437-1445

Gao Y, Smith G, Alberte R (2000) Temperature dependence of nitrate reductase activity in marine phytoplankton: biochemical analysis and ecological implications. J Phycol 36: 304-313

Gibson CE, Foy RH (1989) On temperature independent growth of phytoplankton. J Plankton Res 11:605-607

Graham D, Patterson DB (1982) Responses of plants to low, non-freezing temperatures: proteins, metabolism and acclimation. Annu Rev Plant Physiol 33:347-372

Harrison WG (1983) Nitrogen in the marine environment: use of isotopes. In: Capone D, Carpenter E (eds) Nitrogen in the marine environment. Academic Press, New York, p 763-807

Huber JL, Huber SC, Campbell WH, Redinbaugh MG (1992) Reversible light/dark modulation of spinach leaf nitrate reductase activity involves protein phosphorylation. Arch Biochem Biophys 296:58-65

Jitts H, McAllister C, Stephens K, Strickland J (1964) The cell division rates of some marine phytoplankters as a function of light and temperature. J Fish Res Board Can 21:139-157

Jumars P, Deming J, Hill P, Karp-Boss L, Yager P, Dade W (1993) Physical constraints on marine osmotrophy in an optimal foraging context. Mar Microb Food Webs 7: 121-159

Kristiansen S (1983) The temperature optimum of the nitrate redutase assay for marine phytoplankton. Limnol Oceanogr 28:776-780

Kudo I, Miyamoto M, Noiri Y, Maita Y (2000) Combined effects of temperature and iron on the growth and physiology of the marine diatom Phaeodactylum tricornutum (Bacillariophyceae). J Phycol 36:1096-1102

La Roche J (1983) Ammonium regeneration: its contribution to phytoplankton nitrogen requirements in a eutrophic environment. Mar Biol 75:231-240

Li WKW (1980) Temperature adaptation in phytoplankton: cellular and photosynthetic characteristics. In: Falkowski PG (ed) Primary productivity in the sea. Plenum Press, New York, p 259-279

Lomas MW, Glibert PM (1999a) Interactions between $\mathrm{NH}_{4}{ }^{+}$ and $\mathrm{NO}_{3}{ }^{-}$uptake and assimilation: comparisons of diatoms and dinoflagellates at several growth temperatures. Mar Biol 133:541-551

Lomas MW, Glibert PM (1999b) Temperature regulation of nitrate uptake: a novel hypothesis about nitrate uptake and reduction in cool-water diatoms. Limnol Oceanogr 44: $556-572$

Lomas MW, Glibert PM (2000) Comparisons of nitrate uptake, storage, and reduction in marine diatoms and flagellates. J Phycol 36:903-913

Loppes R, Devos N, Willem S, Barthelemy P, Matagne RF (1996) Effect of temperature on two enzymes from a psychrophilic Chloromonas (Chlorophyta). J Phycol 32: 276-278

Morris I, Glover HE, Yentsch CS (1974) Products of photosynthesis by marine phytoplankton: the effect of environmental factors on the relative rates of protein synthesis. Mar Biol 27:1-9

Nussaume L, Vincentz M, Meyer C, Boutin JP, Caboche M (1995) Post-translational regulation of nitrate reductase by light is abolished by an N-terminal deletion. Plant Cell 7:611-621

Packard TT, Blasco D, MacIsaac JJ, Dugdale RC (1971) Variations of nitrate reductase activity in marine phytoplankton. Invest Pesq 35:209-219

Parsons T, Maita M, Lalli C (1984) A manual of chemical and biological methods for seawater analysis. Pergamon Press, Oxford

Raimbault P (1984) Influence of temperature on the transient 
response in nitrate uptake and reduction by four marine diatoms. J Exp Mar Biol Ecol 84:37-53

Ratkowsky D, Lowry R, McMeekin T, Stokes A, Chandler R (1983) Model for bacterial culture growth rate throughout the entire biokinetic temperature range. J Bacteriol 154: $1222-1226$

Raven JA, Geider RJ (1988) Temperature and algal growth. New Phytol 110:441-461

Reay DS, Nedwell DB, Priddle J, Ellis-Evans JC (1999) Temperature dependence of inorganic nitrogen uptake: reduced affinity for nitrate at suboptimal temperatures in both algae and bacteria. Appl Environ Microbiol 65:2577-2584

Rhee GY, Gotham IJ (1981) The effect of environmental factors on phytoplankton growth: temperature and the interactions of temperature with nutrient limitation. Limnol Oceanogr 26:635-648

Sakamoto T, Bryant DA (1999) Nitrate transport and not photoinhibition limits growth of the freshwater cyanobacterium Synechococcus species PCC 6301 at low temperature. Plant Physiol (Bethesda) 119:785-794

Shukla SP, Kashyap AK (1999) The thermal responses and activation energy of PSII, nitrate uptake and nitrate reductase activities of two geographically different isolates of Anabena. Cytobios 99:7-17

Smith R, Stapleford L, Ridings R (1994) The acclimated response of growth, photosynthesis, composition, and carbon balance to temperature in the psychrophilic ice diatom Nitzschia seriata. J Phycol 30:8-16

Editorial responsibility: Otto Kinne (Editor), Oldendorf/Luhe, Germany
Solomonson LP, Barber MJ (1990) Assimilatory nitrate reductase: functional properties and regulation. Annu Rev Plant Physiol Plant Mol Biol 41:225-253

Solomonson LP, Vennesland B (1972) Properties of a nitrate reductase of Chlorella. Biochim Biophys Acta 267:544-557

Suzuki Y, Takahashi M (1995) Growth responses of several diatom species isolated from various environments to temperature. J Phycol 31:880-888

Terry K (1983) Temperature dependence of ammonium and phosphate uptake and their interaction in the marine diatom Phaeodactylum tricornutm Bohlin. Mar Biol Lett 4: 309-320

Thompson PA, Guo M, Harrison PJ (1992) Effects of variation in temperature. I. On the biochemical composition of eight species of marine phytoplankton. J Phycol 28:481-488

Vergara JJ, Berges JA, Falkowski PG (1998) Diel periodicity of nitrate reductase activity and protein levels in the marine diatom Thalassiosira weissflogii (Bacillariophyceae). J Phycol 34:952-961

Whalen SC, Alexander V (1984) Influence of temperature and light on rates of inorganic nitrogen transport by algae in an Arctic lake. Can J Fish Aquat Sci 41:1310-1318

Witt FG, Stohr C, Ullrich WR (1999) Soluble and membraneassociated nitrate reductases in the dinoflagellate Peridinium gatunense. New Phytol 142:27-34

Yoder J (1979) Effect of temperature on light-limited growth and chemical composition of Skeletonema costatum (Bacillariophyceae). J Phycol 15:362-370

Submitted: October 16, 2000; Accepted: April 19, 2001 Proofs received from author(s): January 8, 2002 